UNRAM Law Review is licensed under a Creative Commons Attribution 4.0 International License, which permits unrestricted use, distribution, and reproduction in any medium,

provided the original work is properly cited. p-ISSN: 2548-9267 | e-ISSN : 2549-2365,

Open Access at : http://unramlawreview.unram.ac.id/index.php/ulr

Volume 5 Nomor 1 April 2021

\title{
The Policy on Law Enforcement of Illegal Sand Mining on Special Region of Yogykarta
}

\author{
Muhammad Purwaka \\ Universitas Muhammadiyah Yogyakarta \\ Email:muhpurwoko@gmail.com
}

\begin{abstract}
The research aims to analyse the law enforcement on the illegal sand mining in the special region of Yogyakarta as well as to acknowledge the obstacle on the law enforcement concerning illegal sand mining and how to cope with the obstacle concerning the illegal sand mine in the special region of Yogyakarta. The research method in this research is a qualitative legal method by using the normative and doctrinal approach. The result shows that a local government has tried several actions to solve or enforce the law to the illegal sand miners, some of them are through the peal action where a conviction is done to raises deterrent effect to the perpetrator. The criminal sanctions to the perpetrator of sand mine according to the article 158 act number 3 years 2020 concerning the amendment of the act number 4 years 2009 concerning mineral and coal mine, the sanction to the perpetrator of illegal mining is an imprisonment penalty for 5 years and fine in a maximum of Rp. 100.000.000.000 (hundred billion rupiahs). While the non-penal means is by implementing the coaching and counselling to the society, in purpose to have a preventive action so that the society will not doing illegal mining without a permit.
\end{abstract}

Keywords: Policy; Law Enforcement; Illegal Sand Mining

\section{INTRODUCTION}

One of the potential Resources in the special region of Yogyakarta is mineral type C. to arrange this mining resource of type $\mathrm{C}$ the mining actors have to own the people's mining permits. The people's mining permit purpose is to provide chances for the local society to exploit the minerals in participating to develop the country in the field of mining under the supervising of the government. By the existence of this mining activity particularly the type $\mathrm{C}$ could contribute to the region as well as to help the society to develop their welfare which is still very low.

By virtue of the act number 23 years, 2014 concerning the regional government stated that the permit issuance of mining business is switched to the province. The regulation of people's mining permit in the special region of Yogyakarta is stipulated under the governor regulation of the special region of Yogyakarta number 110 years 2015 concerning the implementation of people's mining activity which stated that the permit of people's mining which then known as IPR is a permit to implement the mining business in the region of people's mining with a limited area and investment. 
There are many violations done by the businessmen in carrying out their mining business activities especially in the field of sand mining in the special region of Yogyakarta. The governor of the special region of Yogyakarta "Sultan Hamengkubuwono X" stated that $70 \%$ of the mining in the region is illegal. During the mining permit under the authority of the district and city government, there are only 22 legal mining, and the rest of it about $70 \%$ of it is illegal". ${ }^{1}$

It is recorded that from 2015 to 2017, the police have conducted a hand arrest operation 32 times to the perpetrator of illegal mining in the area of the special region of Yogyakarta. According to the public works services agency of housing and mineral resources (in short terms known as DPUP ESDM), the hand arrest operation (OTT) of illegal sand miners mostly occurred in the year 2015 with the amount of 14 operations, subsequently, in 2016 and 2017 there is nine hand arrest operation of the illegal sand miners in the special region of Yogyakarta. ${ }^{2}$

According to the background statement above, there are still occurred a lot of illegal sand mining in the special region of Yogyakarta and following the regulation in this matter is the act number 4 the year 2009 concerning the coal and minerals and other provision as amended under the act number 3 the year 2020, the licensing according to the regional governor of the special region of Yogyakarta number 110 the year 2015 concerning the implementation on people's mining permit activity, it is important to research and study on how is the effort of the government of the special region of Yogyakarta to enforce the law of an illegal sand mining as well as to acknowledge the obstacle in the law enforcement of this cases in the special region of Yogyakarta.

\section{METHOD}

The type of this research is an empirical juridical study, which is the result of collecting and finding the data as well as the information through the field study on the assumption or basic presumption which is used to answer the problem of this research, then tested through the inductive verification on the latest facts which occurred in the society. The resource of the data is primary and secondary data, which is data that comes from documentation, books or literature, and other files that are related to the problem of the research. This research was held in the special region of Yogyakarta which focused on three district areas which are the district of Sleman, the District of Bantul, and the district of KulonProgo. The data analysis technique is a qualitative method used for the normative (juridical) aspects through the descriptive analysis method which is done by outlines the data description concerning the law enforcement of an illegal sand mining based on the interview result and documentation which will be analysed with the theory of law enforcement by connecting each other to get a general conclusion. Form

\footnotetext{
${ }^{1}$ https://bisnis.tempo.co/read/690669/sultan-70-persen-penambangan-di-yogyakarta-ilegal, (Accessed on January 17, 2021)

${ }^{2}$ http://www.jatengpos.com/2018/01/hukuman-penambang-ilegal-di-diy-belum-menjerakan-883306, (Acsessed on January 2021)
}

90 Muhammad Purwaka | The Policy on Law Enforcement of...... 
the analysis result it is known and obtained the inductive conclusion, which is the method of thinking in taking the conclusion generally according to the special facts. ${ }^{3}$

\section{ANALYSIS AND DISCUSSION}

\section{The Law Enforcement On The Illegal Sand Mining In The Special Region Of Yogyakarta}

The provision in the field of mining regulated under article 158 to the article 165 of the act number 4 years 2009 concerning coal and minerals mining, the regulation is covered as a special criminal action because it arises danger which will impact the loss to society, so that this regulation regulated with the heavy and high criminal sanctions.

The impact of illegal mining may arise damage to the environment and could disturb the balance of the natural ecosystem, where the action this illegal mining was id done in the agriculture and plantation that has significant productivity, by virtue of the act number 4 years 2009 under article 158 stated that " everyone who does mining business without mining license (whether in the form of IUP, IPR or IUPK) will be sentenced to imprisonment for ten years maximum and fine for ten billion Rupiah (Rp. 10. 000.000.000,00". While the criminal charges by virtue of the act number 3 years 2020 concerning minerals is the longest for years maximum and fine at the most cost of Rp. 100.000.000.000,00 (hundreds billion Rupiah).

It can be interpreted that whoever who does the sand mining business which against the regulation and for the perpetrators who does the illegal sand mining activity or even for the law enforcer who should be working to create legal conformity however at this matter even covered the activity that could be sentenced to crime as mentions under the articles. there are four stages to enforce the law to the sand miners who do not have a license:

The first is a pre-emptive stage, which is the enforcement of the law where the regulation must be known by the society or the sand miners through the socialization, concerning the mining which performed by the concerned agency, at the time the department of water resources and minerals energy resources of the province of DIY together with the agency of environment cooperated with the civil service security guard. The party of Department of Energy and Mineral resources also have done preventive action by doing direct and written appeal to the sand miner so that they could take care of the people's mining licensing business in the official authority and not mining illegally so that there won't be any loss to the region.

Second is a preventive measure which is done by way of patrols to the regions or location where there is occurred much violation of sand mining which performed illegally also by doing supervising such as appeal to the illegal sand miners to apply for their permit in a period of 7 days. If it's not finished yet, it will be extended for 3 days and extend more for 3 days if the licensing process has not been completed. The police through the community development

\footnotetext{
${ }^{3}$ Soerjono Soekanto. (1986). PengantarPenelitian Hukum. Jakarta: Universitas Indonesia Press, p. 112
} 
sector has done the preventive measure such as appeal whether in the written and oral forms to the society so that there will be no illegal sand mining along the river in the region of the special region of Yogyakarta.

The third is non yustisi preventive stage is a stage where the direct action is performed by the law enforcer by way of foreclosure on the tools/goods that are used by the miners to mine the sand. As mentions by the directorate of police special criminal investigation of the special region of Yogyakarta stated that they have captured BS (41) who is the perpetrator of the criminal act of illegal sand miners by using a suction machine in the Progo river, Minggir, the district of Sleman. The Head of public relations of the police department of the special region of Yogyakarta (the police chief commissioner) Yulianto stated that the arrestment of BS is done according to the police report on 21st January 2020. " the concerned subject have done sand mining by using a suction machine without permit such as mining business license (IUP), people's mining permit (IPR), or special mining business license (IUPK). The suspect was arrested as the owner of a suction machine which modified and at once as the person in charge of the illegal sand mining in the Progo river, at the north of Ngapak bridge, Minggir, District of Sleman.

The police have secured some evidence from the suspect and witnesses, between them are two units of modified suction machines, three pipes, two blue hoses, and one unit dump truck. For his actions, BS suspected of violating article 158 of the act number 4 years 2009 concerning minerals and coal mining under the threat of imprisonment for 10 years maximum and fine for Rp.10 billion.

The fourth step is judicial repressive where the perpetrator of illegal mining who has caught raids and makes a statement if they still stubborn to do the illegal mining then the apparatus will seizure and investigate the illegal sand miners to be processed in the court.

There are several steps on processing the criminal sanction to the illegal sand miners perpetrator until finally the force of law remains,

a. Investigation as the series of actions of investigator in researching and finding an event which is presumed as the 10 criminal act to determines whether or not it can be investigated according to the law, the investigator is the police officers of the Republic of Indonesia which held the authority by the act to do the investigation.

b. An investigation is the series of actions of the investigator in matters of and according to the way which regulated under the law to seek and collect evidence which by the evidence will make clear concerning the criminal actions that occurred and to find the suspect. Andi Hamzah in Mukhelis stated, "An investigation is a process or ass a first step which is a settlement of criminal acts that needs to be investigated and search thoroughly under the criminal law 
system". 4 An investigator is a police of the Republic of Indonesia or special government employees who are given special authority by the law to the investigation. ${ }^{5}$ The purpose of the investigation is to point who committed the crime and provides evidence concerning the problem to reach the meaning then the investigator will collect information according to the facts or particular events. ${ }^{6}$

c. Prosecution

d. The prosecution is an action by the prosecutor to delegate criminal cases to the district court which had the authority on the matters and according to the procedure under the law by the request so that it will be examined and decides by the judges in the court trial. A prosecutor is an office that is given authority by the law to act as the public prosecutor also implementing the court decision which has obtained permanent legal force. The public prosecutor is a prosecutor which given authority by the law to do the prosecution and implementing the judges' statutes.

e. adjudication

adjudication is a series of judges' action to accept, examines and decides criminal cases according to the principle of freedom, honesty, and non-discrimination in the court trial in the matter of and according to the way which regulated under this law, a judge is an official state trial which has the authority by the law to judge.

f. Court sentence

The sentence is a statement by the judge spoken in the open court trial which can be in the form of conviction or acquittal or free and every lawsuit according to the regulation under the law.

The law enforcement on the action of illegal coal mining is implemented by the police, prosecutor and judge based on the procedures with the duties and authorities from each of the legal department and between those legal enforcers synergized with each other in the effort of legal enforcement according to the act number 4 years 2009 concerning the minerals and coal mining as amended with the act number 3 years 2020 .

In the opinion of the writer, in the criminal conviction whether the public prosecutor and judges using the combined criminal theory between absolute theory (counter-theory) and also the relative theory (goals theory), that a conviction which convicted other than to give a deterrent effect, the purpose of the criminal sanctions is also to improve oneself so that they will not repeat the same criminal mistakes and also to prevent other people to do the same thing, in this matter is an action of coal mining without a permit from the special region of Yogyakarta province. Apart from the absolute theory and relative theory, whether the police,

\footnotetext{
${ }^{4}$ Mukhlis R. (2013). "Pergeseran Kedudukan dan Tugas Penyidik POLRI Dengan Perkembangan Delik-Delik di Luar KUHP”. Jurnal Ilmu Hukum, 3 (1)

${ }^{5}$ Article (1) para 01 (penal code)

${ }^{6}$ M.Huseinharun, Op, Cit.p.58
} 
prosecutor, and judges also put forward the progressive law, since under the law enforcement of illegal coal mining is not only viewed from the normative way but also viewed through the sociology way, because the result of the mining of sand if it seen from the economic values is still low compared to the coal and others that had higher economic values.

Economic values is still low compared to the coal and others that had higher economic values.

A criminal action of mining may be determined from its types. The first is mining without even have any license, second is mining with an expired permit. The third is doing the mining in the outside area or out of the coordinate point that has been determined under the permit. Fourth is doing the mining by utilizing the permit which is not following the designation. ${ }^{7}$

Talk about the aspect of criminal activity to the society of illegal sand mining, sure is connected strongly with the criminal responsibility from the perpetrators of the illegal sand mining and is not separated from the aspect of guilty which in purpose to justify the legal action which necessary to be taken by the court. Criminal law Requires that a sentence to the perpetrators of illegal sand mining is comparable with the fault. How big the negative effect of illegal sand mining to the environment, the presence or absence of warning or appeal from the apparatus of law enforcer and the government which naturally suggested the society to not perform mining without a permit even though the reason for this matter as a source of income, it is the reason on the sentencing penalty. The police in law enforcement to the perpetrators, when there is a report from the society which is presumed as a criminal action and found directly by the officer, then the police will do the law enforcement in the field of mining which is processed according to the procedures and applicable law.

\section{The Obstacles and Efforts on Law Enforcement Against Unlicensed C Mining in The Special Region of Yogyakarta}

In the efforts of law enforcement to the illegal sand mining determines several regulations which regulated the concerning matters, however there is still occurred several obstacles on the implementation, which are:

a. The lack of legal awareness in the society

Legal awareness is a factor in the legal finding. The realization of the law means an awareness that the law is the protector of interest for society. The lack of this legal awareness arises more action which violated the legal rules which have been regulated under the law. The society that is not getting used to the administration is one of the obstacles in eradicating this illegal mining of the sand, the existence of the provision under the government act which stated that every licensing bestowed to the office of governor is getting the society to become lazier and pending to apply for the mining license business. From this obstacle, the

${ }^{7}$ Interview with Bapak Pujo Krismanto as a head section of mineral mining ESDM DIY 
government needs to do coaching, supervision, and termination of the mining activities in the danger area (prohibited zone).

b. The lack of coordination between the police department and concerning agency

The lack of coordination between the police department and concerning agency affected the law enforcement which has been done by the police because in the implementation of criminal action investigation process of the illegal sand mining it is indispensable good coordination so that the process on legal enforcement implemented if there is no coordination this matter will hinder the investigation process or the legal enforcement.

Based on the description above, it can be concluded that to be able to enforce the law on the criminal activities of illegal sand mining in the special region of Yogyakarta, it is needing good collaboration and coordination between the apparatus of legal enforcement, the concerning agency, and other security forces, by virtue of the applicable law particularly in the matters of criminal mining action. The effort to cope with illegal sand mining is done through preventive measures and repressive measures.

The preventive effort is a countermeasures effort that emphasizes more on the preventive or control before the criminal act of illegal sand mining has occurred, while the repressive effort is an effort which is more of character on the oppression/eradication or crackdown after the crime of illegal sand mining occurred. This repressive effort was dominantly done by the police.

c. The lack of societies knowledge on the impact of illegal sand mining

Part of the society is a lack of understanding of the environment and also the importance in protecting the environment, a sand mining is not only providing benefits and advantages but also causing troubles. The knowledge of the societies concerning the permit of sand mining also still lacking, this matter causes wider mining area, this matter is also pushed by the economic factors which faced by the society. The activities of sand mining that using heavy equipment which function to dredge the materials arises ecologic and social problems to the surrounding environment.

d. Economic factors

An economic factor is the most vulnerable thing that triggers the crime. By the existence of economic obstacle which occurred in the society pressing them to do the criminal action. The level of society's economy determines by the chance to get the income resource, employment opportunity, and business opportunity. society often faces obstacles such as difficulty in finding a job and another factor is a discrepancy between work results with the profit, with the opportunity to mine the sand, most of them hanging their life from the earnings of the sand mining. So, in this situation, the existence of sand mining provides some profit for a bunch of the society who is involved whether as labour or even as an investor. 
e. The factor of law enforcement

The factor of law enforcement is one of the pushed factors of illegal sand mining criminal action occurred. The enforcement of the law according to Satjipto Rahardjo is an enforcement of the law essentially is the foundation of the ideas or concepts concerning justice, truth, social benefits, etc. therefore, law enforcement in an effort to manifest these ideas and concepts become reality.

The weakness of law enforcement is a causative factor the rampant illegal sand mining crime, the weakness of supervision and law enforcement impressed to provide discretion and is not deter the perpetrator. This is because of the low in cases settlement of the illegal sand mining. In criminal law enforcement, several steps is required to get through, among others:

1. The formulation stage is in abstraction law enforcement, which is done by the legislators, this stage is also called as legislative policy stage. In this stage, the regulation is made

2. The application stage is a stage where the law applied by the apparatus of law enforcement started from the police department until reaching the court. This stage also called as judicative policy.

3. The execution stage is a stage of concrete execution of the crime by the apparatus of the criminal implementor. This stage also called executive or administrative policy

Criminal law enforcement is a process of law implementation to determine what is according to the law, which is can be punished or convicted according to the provision under material criminal law, by guidance on how to act or the efforts that are required for the continuity of the good applicable law, before even after the act of law violation occurred by virtue of the provision under formal criminal law.

The role of the law enforcer in the implementation of criminal law is as a front line, the apparatus of law enforcement should be assertive in performing its function according to the law to tackle the criminal action on illegal sand mining. The other matter which is also important in the process of criminal law enforcement is the society itself. Society should realize that the process of law enforcement is not merely the responsibility of the law enforcer, however, it also including the responsibility of the society in the effort of facing and overcome any form of crime that will be lost and unsettling the society. The awareness of the society Is the key point that is important that needs be in the society however, it is often to be found some from the society are not aware yet of their role in supporting the law enforcement.

\section{The Efforts in tackling the practice of illegal sand mining}

To tackle the practice of illegal sand mining that is occurred, the approach efforts are:

a. Upgrading the coordination with every concern parties

The implementation of police duties and function as the department oflaw enforcementand eradicate the criminal act of illegal sand mining is always trying to upgrade the performance 
so that it will create law enforcement under the law enforcement which is expected by the society. Therefore, the effort to prevent and reduce the action of mining without a special permit. If the perpetrator is indicated as the person of apparatus of law enforcement, ask the stakeholder and society to report the deviant action which has been done by the persons to the police.

b. Conducting socialization to increase the public legal awareness

Socialization is development process of the human potency through the absorption of value, norms and diverse of cultural aspects of the society completely. Socialization enables people to act according to the value and norms that applied in the society so that they will be spared from asocial behavior or behavior which is against the value and norm in the society. One of the factors the rampant of crime of the illegal sand mining is the minimum of socialization which performed by the regional government to the society in the area concerning the regulation on the mining as well as it criminal sanctions.

c. Conducting patrols and raids on mining activities without permit on regular basis

The effort which conducted by the apparatus in minimize the practice illegal mining is by restrict patrols in the surrounding area of mining, the patrols is conduct by checking the completeness of the documents or letters that related with transport and sand mining. To increase the supervision, it will be formed an integrated team consisting of the police, regional government through the concerning agency, and attorney to do the special operation on countermeasures and crime control of mining without permit. The patrols ic conduct on regular basis as the effort to prevent the mining without permit.

\section{CONCLUSION}

The policy on sand mining in the special region of Yogyakarta according to the act number 4 years 2009 concerning coal and minerals is by release a policy of regional regulation of special region of Yogyakarta number 1 years 2018 concerning business management of metal mineral mining, nonmetal minerals and coals, and the governor regulation of the special region of Yogyakarta number 57 years 2017 concerning the amendment of governor regulation of special region of Yogyakarta number 110 years 2015 on the implementation of community mining permit as the first requirement to held a business and/or mining activity is required to have a permit in the form of IPR (people's mining permit), where this permit issued by an authority official the agency of (PUP and ESDM) of special region of Yogyakarta. after the enactment of the act number 3 years 2020 concerning coal and mining, the policy $f$ the regional government of special region of Yogyakarta is held a moratorium (temporary suspension) based on the article $173 \mathrm{C}$ number 3 years 2020 or according to the letter of general of mineral and coal of the ministry of energy and mineral resources number 742/30.01/DJB/2020 concerning 
the postponement of the issuance of new license in the mineral and coal mining sector to governors throughout Indonesia.

The law enforcement to the perpetrators of illegal mining in the special region of Yogyakarta implemented through the stage of examination, investigation conducted by the investigator which is a police officer of the Republic of Indonesia or a special government servant who has been given authority by the law to do the investigation, prosecution to delegating the criminal cases to the court, subsequently, the judges will try and decides the criminal action of illegal sand mining by virtue of the law. The implementation of law enforcement in the special region of Yogyakarta purpose is have a deterrent effect to the perpetrator of illegal mining. On the other hand, the, non-litigation process conducted through the coaching and appeal to the society, which purpose as a preventive effort of the illegal mining in the society. Furthermore, the factors that obstacle the law enforcement in the matter of illegal mining in the special region of Yogyakarta is the lack of public legal awareness, the lack of coordination between the stakeholder such as police and other concerns agency concerning licensing, the lack of society's knowledge on the impact of illegal sand mining and other factors of the law enforcement which is the weakness of law enforcement. Lastly, the effort in tackling this illegal mining practice is by upgrading the coordination together with every party, conducting socialization in order to upgrade public awareness as well as conduct patrols and raids of the mining activities permit on the regular basis.

\section{Bibliography}

Soerjono Soekanto. (1986). PengantarPenelitian Hukum. Jakarta: Universitas Indonesia Press,

Mukhlis R. (2013). "Pergeseran Kedudukan dan Tugas Penyidik POLRI Dengan Perkembangan Delik-Delik di Luar KUHP”. Jurnal Ilmu Hukum, 3 (1)

Article (1) para 01 (penal code)

https://bisnis.tempo.co/read/690669/sultan-70-persen-penambangan-di-yogyakarta-ilegal, (Accessed on January 17, 2021)

http://www.jatengpos.com/2018/01/hukuman-penambang-ilegal-di-diy-belummenjerakan-883306, (Acsessed on January 2021)

Interview with Bapak PujoKrismanto as a head section of mineral mining ESDM DIY 